\title{
REMUNERATION OF INDEPENDENT DIRECTORS: DETERMINANTS AND POLICY IMPLICATIONS
}

\author{
Massimo Belcredi ${ }^{*}$, Stefano Bozzi ${ }^{* *}$ \\ * Catholic University "Sacro Cuore", Milan, Italy \\ ** Corresponding author, Catholic University "Sacro Cuore", Rome, Italy \\ Contact details: Catholic University "Sacro Cuore", Largo Vito, 1, 00168 Rome, Italy
}

OPEN $\odot$ ACCESS

How to cite this paper: Bozzi, S., Belcredi, M. (2019). Remuneration of independent directors: Determinants and policy implications [Special issue]. Corporate Ownership \& Control, 17(1), 278-291. http://doi.org/10.22495/cocvl7ilsiart10

Copyright $@ 2019$ The Authors

This work is licensed under a Creative Commons Attribution 4.0 International License (CC BY 4.0).

https://creativecommons.org/licenses /by/4.0/

ISSN Online: 1810-3057

ISSN Print: 1727-9232

Received: 18.10 .2019

Accepted: 24.12 .2019

JEL Classification: G32, G34, G38 DOI: $10.22495 /$ cocvl 7 il siart 10

\begin{abstract}
Taking advantage of a unique database on Italian Corporate Governance, we study the determinants of remuneration paid to individual non-executive directors (NEDs) and, in particular, to independent directors (INEDs). Our results on a database covering around 16,000 positions/year for non-executive directors in Italian listed firms (over a 9-year period) show that: 1) Remuneration is strongly affected by firm characteristics, in particular by firm size. Independent directors are paid less than gray directors; the gap between the two categories is, however, gradually closing, due to lower additional compensation being paid to gray directors in subsidiaries. Contrary to what happens in other countries, NED remuneration remained quite stable: a small increase is observable only for independent directors; 2) NED remuneration is influenced by the functions performed by individual directors within the board. On the contrary, individual directors' characteristics have little or no impact. We find evidence of a gender pay gap among independent directors in less recent years; however, this gap has gradually disappeared in conjunction with the increasing number and role of female directors, following the adoption of gender quotas; 3) The relationship between independent directors' pay and some variables of interest has changed over time: this is true not only for gender but also for Tobin's Q (a proxy for the benefits from monitoring) and for the number of positions held in other companies. The changes we observe are apparently consistent with the market for directors' pay in Italy becoming more mature after the introduction of Say-on-Pay and other regulation favouring investor activism. This is also consistent with a positive role played by both institutional investors and their representatives sitting on the board of listed companies after the introduction of said legislation.
\end{abstract}

Keywords: Corporate Governance, Independent Directors, Board Compensation

Authors' individual contribution: Conceptualization - M.B.; Methodology S.B.; Formal Analysis - S.B.; Data Curation - M.B.; Writing - Original Draft - M.B.; Writing - Review and Editing - S.B.

\section{INTRODUCTION}

"To understand boards we need to understand the people who sit on them" (Adams, 2017).

Non-executive (and independent) directors serve a number of important functions on the board of directors, such as monitoring management and contributing to strategic decision-making. They also contribute a valuable set of resources and bring experience to the firm.

In the past two decades, starting with the UK Cadbury Code, increasing independence at the board level has become a global mantra: indeed, nonexecutive (and independent) directors have received 
increasing attention both in regulation and in selfregulation as a mechanism for controlling management decisions, avoiding conflicts of interest and strengthening firm governance. ${ }^{1}$

In this context, NED remuneration is a topic of paramount relevance, in light of the impact it may have on the behaviour of independent directors. The available evidence shows that NED remuneration policy is quite variable, both at the country and at the firm level. The level of NED remuneration in Europe is apparently lower than in the US Korn-Ferry (2016) reports, for a sample of large listed firms, that NEDs' (excluding non-executive chairmen) median "basic" remuneration varies a lot across countries, between $€ 20,000$ in France and $€ 90,000$ in Germany; additional fees of $€ 10,000$ to 40,000 (median values) are then paid to members of board committees. A partial explanation for lower remuneration in European firms lies in local Corporate Governance Codes, which often recommend to avoid variable (and, especially, stockbased) remuneration for NEDs and, in particular, for independent directors (this is the case both in the UK and in Italy). Consequently, the structure of NED remuneration also differs across countries. NED remuneration is generally growing over time, presumably in response to additional demands by both regulation and investors.

We analyze NED remuneration in Italian firms over a rather long period (2007-2015); this allows us to investigate changes in remuneration policies and determinants over time. In particular, we test the impact of three groups of factors possibly affecting remuneration: firm characteristics, directors individual qualities and the functions NEDs perform within the board.

At the start of our sample period (in 2007), NED remuneration in Italy was broadly in line with UK levels (and considerably higher than in Germany); however, contrary to what happened elsewhere, remuneration remained pretty stable over time; a small increase (around 10\%) is observable only for independent directors.

In line with theoretical predictions, we show that NED (and in particular independent directors') remuneration is heavily influenced by firm characteristics and, to some extent, by the functions NEDs perform within the board, while individual director characteristics are apparently less important. Furthermore, while remuneration remained stable, the influence of specific determinants varied remarkably over time. After the enactment of important legal reforms (gender quotas, Say-on-Pay, and adoption of EU shareholder rights directive) the relationship between remuneration and firm (individual) characteristics has changed in a way that is consistent with a more mature market for directors' pay. Our evidence is broadly consistent with a positive role played by institutional investors and their representatives sitting on the board of listed companies after the introduction of said legislation. Further research is needed to address this issue.

The rest of the paper is organized as follows. Section 2 presents an overview of the existing

${ }^{1}$ Only after the 2007/09 financial crisis the potential drawbacks of a independent board (in contrast to a "professional" one), at least in financial institutions, have started to draw the attention of commentators (Becht, Bolton, \& Röell, 2012; Armour, Awrey, Enriques, Gordon, Mayer, \& Payne, ; Armour, Awrey, Enriques, Gordon, Mayer, \& Payne, 2016). literature. Section 3 describes the Italian institutional framework. Section 4 presents our sample, provides some descriptive statistics and describes our methodology. Section 5 reports and comments on our results. Section 6 concludes.

\section{LITERATURE REVIEW}

In an agency framework, NEDs are seen as delegated monitors on behalf of (outside) shareholders and their action may imply costs as well as benefits; furthermore, as in any agency relationship, there is no reason to expect a priori that they will be an efficient solution to the original agency problem unless a proper system of incentives is in place. ${ }^{2}$ Remuneration policy is crucial in this regard (even though reputational effects may be an additional powerful incentive: Masulis \& Mobbs, 2014). Actually, Adams and Ferreira (2008) find that director attendance is influenced even by trivial variations in remuneration (such as those implied by attendance fees). In the same vein, Nguyen (2014) finds that both meeting fees and variable remuneration have an impact on directors' incentives and activity, while Hope, Lu, and Saiy (2019) find a positive correlation between the levels of compensation of independent directors and related party transactions.

As highlighted by Adithipyangkul and Leung (2016), while there is extensive research on the determinants of senior executives' remuneration, and its possible effects on firm value, relatively little is known about the remuneration of non-executive directors (NEDs) and, in particular, of independent directors (INEDs), i.e., NEDs who have no personal or business relationship with managers or "large" shareholders, in contrast to "gray" non-executive directors (Hermalin \& Weisbach, 1988), who may have such relationships.

The available evidence shows that NED remuneration policy is quite variable, both at the country and at the firm level. Fedaseyeu, Linck, and Wagner (2018) show that US firms paid an average (median) remuneration of $\$ 170,000(164,000)$ to NEDs in the 2006-2010 period; this included a cash fee of around $\$ 69,000(65,000)$ plus stock and option awards for additional $\$ 95,000 \quad(50,000)$. Variable remuneration accounted for a significant portion of the total. NED remuneration has grown remarkably over time (Yermack, 2004; Ryan \& Wiggins, 2004; Farrell, Friesen, \& Hersch, 2008; Linck, Netter, \& Yang, 2009; Fedaseyeu et al., 2018), also in response to increasing responsibilities deriving from new regulation (e.g., Sarbanes-Oxley: see Engel, Hayes, \& Wang, 2010 for audit committee members).

Previous literature on the determinants of NED remuneration is mostly limited to the US. Seminal articles are Bryan, Hwang, Klein, and Lilien (2000), finding that board compensation is structured to mitigate agency problems where management control is separated from ownership, and Brick, Palmon, and Wald (2006), showing that director remuneration is related to variables proxying the need for monitoring and the difficulty of directors'

${ }^{2}$ In this regard, Masulis and Zhang (2019) show that firms whose independent directors are distracted by exogenous events have declining firm valuation profitability and accounting quality. 
tasks (Dah \& Frye, 2017). Fedaseyeu et al. (2018) show that NEDs' remuneration does not depend only on firm characteristics but also on the role they play within the firm (as proxied by the number of board committees they sit on) and that this, in turn, is related to director qualifications, defined in terms of previous "experience".

European evidence is extremely limited: Goh and Gupta (2015) show that average (median) NED remuneration increased from $£ 57,100(30,000)$ to $£ 110,300(66,000)$ over the 2001-2012 period. Excluding non-executive chairs, values are lower but show the same evolution over time: average (median) remuneration increased from $£ 34,400(28,000)$ to $£ 70,000(57,000)$. NED remuneration in UK firms is linked both to firms' and to directors' individual characteristics: age, tenure and network size are positively related to remuneration, suggesting that directors' ability to contribute to board decision-making and their set of resources are valued by firms. NED remuneration in the UK is negatively related to monitoring characteristics such as director independence; consequently, Goh and Gupta (2015) argue that the implied incentive system might be suboptimal since effective monitors of top management are paid less than other directors. They also find evidence of an (arguably suboptimal) gender pay gap (female directors receive lower remuneration).

Andreas, Rapp, and Wolff (2012) provide evidence about the determinants of NED remuneration in the German two-tier system. They show that average compensation per director (a member of the supervisory board) is rather low (around $€ 38,000^{3}$ ) and that a majority (61.2\%) of listed firms makes use of performance-based compensation elements. Also in Germany, director compensation is growing over time: average (median) NED remuneration increased from $€ 32,100$ $(20,000)$ in 2005 to $€ 42,000(27,000)$ in 2008 ; pay growth is driven by non-performance-based compensation (fixed retainer + attendance and/or committee fees). Director compensation in Germany is related not only to firm size but also to corporate performance, ownership structure and, to a limited extent, board characteristics.

Taking advantage of a unique database on Italian corporate governance data, we bring new evidence ${ }^{4}$ on the determinants of non-executive (and independent) directors' remuneration and derive policy implications on this point. The Italian context is sufficiently original to deserve careful consideration from an international point of view. The "traditional" governance system ${ }^{5}$ adopted by almost all Italian firms is sufficiently similar to the Anglo-Saxon one-tier system; Italian firms are usually controlled by a majority shareholder (holding - on average - $49 \%$ of equity capital), as in other continental European countries. Corporate governance reforms implemented over the last 20 years have considerably strengthened investor

${ }^{3}$ This is much lower than the values reported by Korn-Ferry (2016), which

refer to a small number of blue chips.
${ }^{4}$ To the best of our knowledge, the only study based on Italian data so far is ${ }^{4}$ To the best of our knowledge, the only study based on Italian data so far is
Mallin, Melis, and Gaia (2015), a small sample analysis on matched pairs of Mallin, Melis, and Gaia
Italian and UK firms.

Italian and UK firms.
${ }^{5}$ This is based on a Board of Directors (Consiglio di amministrazione) and a separate Board of Statutory Auditors (BoSA, Collegio Sindacale). The BoSA attends board meetings and monitors: a) compliance with the law and with the company charter; b) the adequacy of the company's organizational structure and of the internal control, administrative and accounting system. protection in Italy, thereby increasing the scope for value-enhancing activism (Belcredi \& Enriques, 2015). Italy looks, therefore, an ideal setting to investigate the effects of changes in the institutional framework favouring investor activism also in the matter of director remuneration.

\section{INSTITUTIONAL FRAMEWORK}

Italy is usually considered a country where low investor protection allows controlling shareholders to enjoy high private benefits; consequently, firm ownership remains concentrated, often in the hands of the founding family, which may make recourse to various instruments to separate ownership from control. Limited role for the disciplining effect of hostile bids, exacerbated conflicts of interest and a high risk of expropriation for minority investors are the natural consequences (Macey, 1998; Dyck \& Zingales, 2004).

This picture is, however, outdated in many respects (Belcredi \& Enriques, 2015). On the one hand, legal reforms have increased investor protection over time, at least in terms of rules 'on the books' (although enforcement may have lagged behind). Minority shareholders are far from defenseless, and they have, in several instances, become active to influence corporate decisions and/or to avoid expropriation. On the other hand, while controlling shareholders' voting rights have remained quite stable (around the 50\% threshold), separation of ownership from control via pyramids and dual class shares has decreased remarkably (Consob, 2017).

The Italian legal framework has traditionally given shareholders a much greater collective power than their US counterparts. As in other European countries (Cools, 2005), Italian companies' GMs have always decided on a broad set of matters and insulation from shareholders has always been hard to achieve for managers, whom shareholders at the GM could (and can) remove at will. This greater power has long been de facto of use only to dominant blockholders, allowing them to keep managers on a tight leash. However, in recent years, proxy fights have started to be used in companies where control was contestable, often giving institutional investors a pivotal role in the vote.

Although mutual funds are rarely expected to be activists, Italian asset managers have taken advantage from an increasingly favourable legal framework, and have become active along three main lines: 1) they put 'pressure' on listed companies (and regulatory bodies) to improve corporate disclosure and to obtain investor-friendly rules of the game, especially via changes in individual company charters and practices; 2) they used their voice and gave negative votes at GMs, where either disclosure was perceived to be insufficient or a deal could imply minority shareholders' expropriation; 3) they submitted slates of candidates for board elections.

One peculiar feature of current Italian corporate governance regulation is, actually, minority shareholders' power to present a slate of candidates to the board and to have at least one candidate appointed even where another slate gains a higher number of votes (Belcredi, Bozzi, \& Di Noia, 2013). This slate voting system was first introduced 
in 1994 in companies undergoing privatization. In 1998, the Consolidated Law on Finance mandated slate voting for the election of boards of auditors in all listed firms. After the Parmalat scandal, lawmakers further strengthened slate voting, by imposing it on all listed companies with regard to the election of directors.

The introduction of slate voting set the basis for coordinating efforts of institutional investors; with specific regard to directors' remuneration, slate voting gave additional leverage to institutional investors where minority representatives are appointed to the board, and may, therefore, influence remuneration policy directly.

A second major change favourable to investor activism took place with the introduction of the record date system after the adoption of the EU Shareholders' Rights Directive in 2010. The new regulation greatly reduced transaction costs associated with GM participation and voting. This proved important especially for foreign institutional investors, which had previously been reluctant to vote their shares in Italian companies. The support by foreign asset managers has become increasingly crucial for the success of mutual fund slates. Under the new regime both the submission of minority slates by Italian asset managers and the support by other institutional investors increased substantially. In general terms, the record date system greatly improved the capacity of institutional investors to coordinate their efforts wherever they see a risk for the value of the securities in their portfolio.

As far as directors' remuneration is concerned, Italian listed companies had been subjected - since 1998 - to mandatory disclosure of the remuneration paid to individual directors. However, shareholders had no opportunity to vote on this issue until recently. Say-on-Pay was first introduced in financial companies; in 2008 banks were required to incorporate in their by-laws rules providing for shareholder approval (i.e., a binding vote) of the remuneration policy concerning board members, managers and employees. A similar regulation was introduced for insurance companies in 2011.

In 2011, SOP was mandated in all Italian listed firms. The new discipline required listed companies to publish a detailed Remuneration Report (RR) made up of two Sections, whose contents have been defined by the market watchdog (Consob). Shareholders are called to express a non-binding vote on the first Section, describing the remuneration policy for the following year and the procedures followed for its adoption and implementation. No vote is provided on the second Section (breaking down last year's remuneration for each board member and providing an analytical representation of every single item). The new regulation enriched substantially the information available to investors, both in financial and nonfinancial companies.

These changes have, in turn, given boost to a market for proxy advisory services. While the role of proxy advisors is still controversial, the informational services they provided have facilitated coordination among institutional investors, in particular in the matter of directors' remuneration and SOP (Belcredi, Bozzi, Ciavarella, \& Novembre, 2017).
In sum, the Italian legal framework has become increasingly favourable to investor activism over time. Directors' remuneration is one of the areas where institutional investors (and proxy advisors selling them their information services) have engaged listed firms more actively, especially in the last few years (Consob, 2017).

\section{SAMPLE AND METHODOLOGY}

To investigate the determinants of NED remuneration, we collected data for all directors sitting on the board of all Italian companies listed on the Italian Stock Exchange over a 9-year period (2007-2015), for a total of 2,288 firm/years. The number of firms listed in each year decreased steadily, from 293 in 2007 to 227 in 2015, due to delistings (mostly connected with bankruptcy procedures and M\&A activity) constantly exceeding new IPOs. Most Italian listed companies are smallmedium enterprises: the average (median) firm had total assets of around $€ 15,500(4,878)$ million. Financial companies account for slightly more than $10 \%$ of the sample. Concentrated ownership prevails: the largest shareholder owns an average (median) stake equal to $49.5 \%$ (53.8\%) of equity capital. Descriptive statistics for our sample are reported in Table 1.

The average board is made up of about 10 directors: around 3 of them are executives, while the remaining 7 are non-executives, approximately 4 of whom are classified as independent. Board size and structure remained pretty stable, while the weight of independent directors has grown slightly over time, from $37 \%$ to $42 \%$ of the board. The average number of minority directors remained stable at 0.7 for almost the whole period; only in 2015 they jumped to 1.8 , due to the increasing activism of Italian asset managers, which started to submit (and appoint) their board candidates also in mid- and sometimes even small-cap companies.

Our sample comprises 16,904 non-executive directors/year $(9,300$ of whom are classified as independent, the remaining 7,604 being "gray" directors). Remuneration and corporate governance data come from the Assonime-Emittenti Titoli annual study on the implementation of the Italian CG Code (Assonime-Emittenti Titoli, 2018). Additional data on individual director characteristics (in terms of education and main profession) were hand-collected from company websites (reporting the $\mathrm{CV}$ of each board candidate in the "materials for the AGM" section). Data on ownership structure are drawn from Consob, while accounting and stock market data come from Datastream-Worldscope.

The average annual NED remuneration is substantially stable around $€ 82,000 \quad(€ 66,000)$ perceived directly from the listed company plus additional $€ 16,000$ from directorships in subsidiaries). We split non-executive directors (NED) into two categories: a) Independent directors, defined according to the Italian CG Code, i.e., directors that do not maintain, directly or indirectly or on behalf of third parties, nor have recently maintained any business relationships with the issuer or persons linked to the issuer; b) Gray directors, i.e., non-executive directors which do have existing or potential business relationships with the firm. 
Table 1. Descriptive statistics

\begin{tabular}{|c|c|c|c|c|c|c|c|c|c|c|c|}
\hline & 2007 & 2008 & 2009 & 2010 & 2011 & 2012 & 2013 & 2014 & 2015 & $\begin{array}{l}\text { Total sample } \\
\text { (mean) }\end{array}$ & $\begin{array}{l}\text { Total sample } \\
\text { (median) }\end{array}$ \\
\hline \multicolumn{12}{|l|}{ Firms Characteristics } \\
\hline N. of firms & 293 & 282 & 272 & 262 & 255 & 239 & 230 & 228 & 227 & & \\
\hline Financial companies (N.) & 37 & 33 & 29 & 28 & 27 & 25 & 23 & 24 & 26 & & \\
\hline Firm size (mean in $€$ million) & 13,100 & 13,800 & 14,100 & 15,300 & 15,900 & 17,200 & 16,700 & 16,800 & 17,900 & 15,500 & 4,878 \\
\hline Tobin's Q & 1.39 & 1.07 & 1.17 & 1.17 & 1.07 & 1.32 & 1.34 & 1.30 & 1.41 & 1.24 & 1.04 \\
\hline Annual stock returns & $-7.7 \%$ & $-49.1 \%$ & $23.1 \%$ & $-3.7 \%$ & $-27.6 \%$ & $1.6 \%$ & $36.0 \%$ & $4.1 \%$ & $19.3 \%$ & $-1.9 \%$ & $-6.0 \%$ \\
\hline ROA & $6.3 \%$ & $2.5 \%$ & $0.7 \%$ & $2.5 \%$ & $-0.6 \%$ & $-14.8 \%$ & $0.7 \%$ & $3.2 \%$ & $3.6 \%$ & $0.6 \%$ & $3.1 \%$ \\
\hline Leverage & 1.49 & 2.05 & 1.29 & 1.68 & 1.81 & 1.47 & 1.78 & 1.91 & 1.62 & 1.68 & 0.92 \\
\hline Volatility & 25.83 & 28.49 & 28.84 & 28.69 & 29.83 & 30.25 & 29.39 & 29.45 & 29.06 & 28.79 & 28.27 \\
\hline Voting rights first shareholder (\%) & $49.0 \%$ & $49.5 \%$ & $50.1 \%$ & $48.8 \%$ & $48.8 \%$ & $50.1 \%$ & $50.4 \%$ & $49.5 \%$ & $49.1 \%$ & $49.5 \%$ & $53.8 \%$ \\
\hline \multicolumn{12}{|l|}{ Board Characteristics } \\
\hline Board size (N.) & 10.1 & 10.1 & 10.3 & 10.4 & 10.4 & 10.3 & 10.2 & 10.1 & 10.0 & 10.2 & 9.0 \\
\hline Non-executive directors (N.) & 7.1 & 7.2 & 7.5 & 7.6 & 7.7 & 7.6 & 7.5 & 7.4 & 7.4 & 7.4 & 6.0 \\
\hline Non-executive directors (\% of board size) & $67.8 \%$ & $68.1 \%$ & $70.0 \%$ & $70.9 \%$ & $71.6 \%$ & $71.1 \%$ & $71.4 \%$ & $71.7 \%$ & $72.2 \%$ & $70.4 \%$ & $71.4 \%$ \\
\hline Independent directors (N.) & 3.8 & 3.8 & 3.9 & 4.0 & 4.2 & 4.3 & 4.3 & 4.3 & 4.4 & 4.1 & 3.0 \\
\hline Independent directors (\% of board size) & $37.0 \%$ & $36.4 \%$ & $36.3 \%$ & $37.7 \%$ & $39.2 \%$ & $40.3 \%$ & $41.2 \%$ & $41.6 \%$ & $42.0 \%$ & $38.9 \%$ & $37.5 \%$ \\
\hline Minority directors (N.) & 0.7 & 0.7 & 0.7 & 0.7 & 0.8 & 0.8 & 0.7 & 0.8 & 1.8 & 0.8 & 0.0 \\
\hline Minority directors (\%) & $6.0 \%$ & $6.1 \%$ & $7.0 \%$ & $6.5 \%$ & $7.1 \%$ & $7.3 \%$ & $7.1 \%$ & $7.1 \%$ & $16.8 \%$ & $7.3 \%$ & $0.0 \%$ \\
\hline \multicolumn{12}{|l|}{ Directors Remuneration } \\
\hline \multicolumn{12}{|l|}{ Non-executive directors } \\
\hline N. & 2048 & 1996 & 2027 & 2001 & 1940 & 1806 & 1724 & 1689 & 1673 & & \\
\hline Remuneration from the issuer $(€ .000)$ & 62.6 & 62.2 & 63.5 & 77.6 & 70.7 & 71.4 & 66.5 & 61.7 & 63.6 & 66.7 & 33.0 \\
\hline Variable remuneration (in \% of non-executive directors) & $2.2 \%$ & $2.2 \%$ & $2.2 \%$ & $1.7 \%$ & $2.1 \%$ & $1.6 \%$ & $2.2 \%$ & $0.7 \%$ & $1.0 \%$ & $1.8 \%$ & $0.0 \%$ \\
\hline Total remuneration (including subsidiaries) (€.000) & 81.3 & 83.7 & 84.7 & 84.4 & 86.0 & 97.2 & 77.8 & 71.9 & 75.3 & 82.7 & 37.0 \\
\hline \multicolumn{12}{|l|}{ Independent directors } \\
\hline N. & 1101 & 1059 & 1057 & 1044 & 1049 & 1030 & 988 & 991 & 981 & & \\
\hline Remuneration from the issuer $(€ .000)$ & 50.0 & 51.0 & 51.2 & 59.5 & 59.3 & 57.4 & 56.1 & 54.0 & 58.6 & 55.2 & 36 \\
\hline Variable remuneration (in \% of independent directors) & $1.5 \%$ & $1.8 \%$ & $2.8 \%$ & $1.3 \%$ & $1.6 \%$ & $1.3 \%$ & $2.1 \%$ & $0.8 \%$ & $0.8 \%$ & $1.6 \%$ & $0 \%$ \\
\hline Total remuneration (including subsidiaries) $(€ .000)$ & 54.1 & 56.3 & 55.4 & 60.8 & 62.0 & 60.2 & 57.9 & 55.7 & 60.2 & 58.0 & 39.0 \\
\hline \multicolumn{12}{|l|}{ Gray directors } \\
\hline N. & 947 & 937 & 970 & 957 & 891 & 776 & 736 & 698 & 692 & & \\
\hline Remuneration from the issuer $(€ .000)$ & 77.2 & 74.9 & 76.9 & 97.4 & 84.2 & 89.8 & 80.4 & 72.5 & 70.8 & 80.8 & 28.0 \\
\hline Variable remuneration (in $\%$ of gray directors) & $3.0 \%$ & $2.7 \%$ & $1.6 \%$ & $2.1 \%$ & $2.6 \%$ & $2.1 \%$ & $2.3 \%$ & $0.6 \%$ & $1.2 \%$ & $2.1 \%$ & $0.0 \%$ \\
\hline Total remuneration (including subsidiaries) (€.000) & 113.1 & 114.6 & 116.7 & 110.3 & 114.2 & 145.7 & 104.4 & 94.9 & 96.9 & 112.8 & 34.0 \\
\hline
\end{tabular}


As shown in Table 1 , remuneration followed a different path for independent and for gray directors: the remuneration of independent directors increased over time; the cumulative growth is however, much smaller $(+11 \%$ over the entire period) than that observable elsewhere. On the other hand, gray directors' pay actually decreased in the same years $(-14 \%$, mainly due to lower remuneration from subsidiaries). Consequently, the pay gap between independent and gray directors has become much smaller, but this is mostly due to a lower remuneration of gray directors.

In line with recommendations of the Italian CG Code $^{6}$, variable remuneration is rarely paid to NEDs: this happened in $1.8 \%$ of the cases; frequency is further decreasing over time (from 2.2\% in 2007 to $1 \%$ in 2015).

To investigate the determinants of NED remuneration we regress proxies for different dimensions of non-executive remuneration (namely, remuneration directly paid by the issuer, total remuneration including sums paid by subsidiaries, and a dummy capturing whether a NED perceived also variable remuneration) on several groups of variables (precise definitions are reported in the Appendix $^{7}$ :

1. Firm characteristics (size, board size, age, risk, past performance - defined both in accounting terms (ROA) and as stock returns - Tobin's Q, ownership structure);

2. NED individual characteristics (gender, number of positions held, tenure, appointment by minority investors, and - for recent years nationality, political connections, and background, in terms of education and main profession);

3. Functions performed by NEDs within the board (committee membership, apical position, i.e. NE Chair or Deputy-Chair).

Regressions, where the dependent variable is NED remuneration (expressed in log terms), are OLS regressions with industry and year fixed effects. Regressions, where the dependent variable is the "variable remuneration" dummy (which can be interpreted as the likelihood that NEDs get variable remuneration), are logistic regressions, with industry and year fixed effects. In both cases, we tried a number of alternative model specifications (including also random, instead of fixed effects) with similar results.

Firm characteristics are known from previous literature to be an important factor affecting directors' pay (both for executives and for nonexecutives). Solid evidence has been found of a strong, positive relationship between remuneration and firm size; for other firm characteristics (complexity, growth, ownership structure, risk, performance) the evidence is less clear-cut. In

\footnotetext{
${ }^{6}$ According to the Italian CG Code "The remuneration of non-executive directors shall not be - other than for an insignificant portion - linked to the economic results achieved by the issuer. Non-executive directors shall not be beneficiaries of share-based compenstion plans, unless it is so decided by the beneficiaries of share-based compensation plans, unless it is so decided by the annual shareholders meeting, which shall also give the relevant reasons. (trector/years. This is true, in particula for individual director characteristics such as "busyness" (the number of other positions held, not always disclosed in CG Reports) and the "long tenure" dummy (equal to 1 if the director has been sitting for more than 9 years on the same board, and 0 otherwise). Since no information is available for pre-IPO periods, this variable may be calculated (for independent directors) only in companies which have been listed for at least 9 years. The same is true for other individual directors' qualities (education, main profession, etc.), which sample size varies with regression specifications.
}

general, we expect NED remuneration to be higher where potential benefits from monitoring are higher, i.e., where complexity (in terms of firm size and growth potential) is higher and where past performance has been disappointing (i.e., lower). The impact of other variables (board size, firm age, ownership structure) is uncertain because contrasting factors may be at work. Take, for instance, ownership structure: a large shareholder may alternatively act as a monitor of managerial decisions or as a self-interested subject extracting private benefits from the firm. Therefore, NED remuneration may depend not only on monitoring needs but also on the influence such a large shareholder has on remuneration policy. Furthermore, where a controlling shareholder is able to influence remuneration, he/she may alternatively try: 1) to win NEDs' friendship by setting a higher pay or 2) to discourage the involvement of highquality professionals in the board, by setting a lower pay. For similar reasons, independent directors may alternatively receive higher or lower compensation: actually, according to previous literature, they seem to be paid less than gray directors.

Individual qualities may influence directors' remuneration: the available evidence has shown a robust relationship with directors' gender (female directors are paid less): this may be due both to social factors, but also to resistance to change by the "old boys' network", i.e., male directors' entrenchment. Additional factors may be directors' reputation and networking capacity ("busy" directors, holding a higher number of positions in other firms, may be paid more, as long as no additional cost derives from their presumably more limited time commitment) and experience (more expert directors, and also directors who have been sitting on the firm's board for a longer period are paid more). We test the relationship of NED remuneration with gender, "busyness", tenure, nationality, education, main profession and also the possible appointment on behalf of minority shareholders. We expect NED (and in particular independent directors') remuneration to be higher for male, foreign ${ }^{8}$, graduate, expert and majority directors. The impact of the number of positions held is uncertain, as is that of tenure: "busy" directors may be characterized by higher reputation but also have less time to commit to board activities (Ferris, Jagannathan, \& Pritchard, 2003; Fich \& Shivdasani, 2006); in a similar vein, "seasoned" directors may have a deeper understanding of the company business, but may also face a higher risk of being "captured" by managers and/or control shareholders through higher pay (Brick et al., 2006). ${ }^{9}$

NEDs may perform various functions within the board and are usually remunerated accordingly. Non-executive chairs are paid more than their board fellows; more in general, remuneration depends on director effort. Previous literature found that remuneration is positively linked to committee memberships and the number of/attendance to

${ }^{8}$ Goh and Gupta (2015) find mixed evidence in this regard in UK firms: American non-executive directors are actually paid more, while other foreign individuals are paid less than their British colleagues.

${ }^{9}$ Independence of individual directors is periodically assessed by the board according to a number of criteria, including the so-called "9-year rule" (a NED does not, in general, appear independent if he/she was a director of the issuer for more than nine years in the last twelve years). The rule is, however, non-binding. 
board meetings. We expect a higher remuneration for NEDs holding apical positions (chair or deputy chair) or sitting in one or more board committees. We also expect the latter effect to varying with the tasks entrusted to the committee (i.e., pay should be higher for Executive Committee and Audit and Risk Committee, and lower for Remuneration Committee members)

We then repeat our analysis on various subsamples, to investigate whether the determinants of remuneration are different for independent directors (in contrast to gray directors) and whether they have changed over time (with particular reference to the introduction of Say-on-Pay legislation, mandating since 2012 a generally nonbinding shareholder vote on Remuneration Reports).

\section{MAIN RESULTS}

Regression results for the whole sample are reported in Table 2.

Table 2. Non-executive directors' (NED) remuneration level and structure

\begin{tabular}{|c|c|c|c|c|c|c|}
\hline & \multicolumn{2}{|c|}{$\begin{array}{l}\text { Remuneration from the } \\
\text { issuer }\end{array}$} & \multicolumn{2}{|c|}{$\begin{array}{c}\text { Total remuneration } \\
\text { (including subsidiaries) }\end{array}$} & \multicolumn{2}{|c|}{$\begin{array}{c}\text { \% of directors with variable } \\
\text { remuneration }\end{array}$} \\
\hline & (1) & (2) & (3) & (4) & (5) & (6) \\
\hline \multirow{2}{*}{ FirmSize } & $0.311^{* * *}$ & $0.308^{* * *}$ & 0.317 *** & $0.314 * * *$ & 0.132 & 0.133 \\
\hline & [12.675] & [12.332] & [12.901] & [12.611] & [1.029] & [1.030] \\
\hline \multirow{2}{*}{ ROA_1 } & $-0.000^{*}$ & 0 & 0 & 0 & 0.012 & 0.012 \\
\hline & {$[-1.719]$} & {$[-1.485]$} & {$[-0.837]$} & {$[-0.593]$} & {$[1.555]$} & [1.526] \\
\hline \multirow{2}{*}{ Stock return_1 } & 0 & 0 & 0 & 0 & 0.002 & 0.002 \\
\hline & {$[0.411]$} & {$[0.413]$} & {$[0.356]$} & {$[0.369]$} & {$[0.579]$} & {$[0.618]$} \\
\hline \multirow{2}{*}{ Firm's age } & 0.059 & 0.066 & 0.097 & $0.103 *$ & -0.11 & -0.11 \\
\hline & {$[0.961]$} & [1.079] & [1.637] & [1.734] & {$[-0.377]$} & {$[-0.375]$} \\
\hline \multirow{2}{*}{ TobinsQ } & $0.163^{* * *}$ & $0.157 * *$ & $0.121 *$ & $0.115^{*}$ & -0.054 & -0.049 \\
\hline & {$[2.295]$} & {$[2.227]$} & [1.845] & [1.782] & {$[-0.147]$} & {$[-0.133]$} \\
\hline \multirow{2}{*}{ StandardDev. } & 0.001 & 0 & 0.001 & 0.001 & -0.014 & -0.013 \\
\hline & {$[0.164]$} & [0.102] & [0.243] & [0.202] & {$[-0.547]$} & {$[-0.522]$} \\
\hline \multirow{2}{*}{ Board size } & 0.001 & -0.016 & -0.054 & -0.071 & $-1.759^{*}$ & $-1.755^{* *}$ \\
\hline & {$[0.006]$} & {$[-0.086]$} & {$[-0.286]$} & {$[-0.378]$} & {$[-1.947]$} & {$[-1.969]$} \\
\hline \multirow{2}{*}{ Ownership concentration } & -0.003 & -0.003 & 0 & 0 & $-0.033^{* *}$ & $-0.032^{* *}$ \\
\hline & {$[-1.009]$} & {$[-1.005]$} & {$[-0.027]$} & {$[-0.010]$} & {$[-2.224]$} & {$[-2.178]$} \\
\hline \multirow{2}{*}{ Minority director } & $-0.139 *$ & $-0.136^{*}$ & $-0.162 * *$ & $-0.158 * *$ & 0.327 & 0.321 \\
\hline & {$[-1.882]$} & {$[-1.855]$} & {$[-2.177]$} & {$[-2.130]$} & [1.152] & [1.133] \\
\hline \multirow{2}{*}{ Gender } & 0.05 & 0.052 & 0.072 & 0.071 & 0.127 & 0.118 \\
\hline & {$[0.787]$} & {$[0.826]$} & [1.246] & [1.219] & {$[0.401]$} & {$[0.373]$} \\
\hline \multirow{2}{*}{ Director busyness } & -0.008 & -0.007 & -0.006 & -0.006 & $-0.081 * *$ & $-0.082^{* *}$ \\
\hline & {$[-1.204]$} & {$[-1.136]$} & {$[-1.013]$} & {$[-0.969]$} & {$[-2.114]$} & {$[-2.152]$} \\
\hline \multirow{2}{*}{ Apical position } & $1.129 * * *$ & $1.147^{* * * *}$ & $0.996^{* * * *}$ & $1.000^{* * * *}$ & $1.145^{* \cdots * * 4}$ & $1.097 * \frac{1}{* * * 4}$ \\
\hline & [12.028] & [12.222] & [11.487] & [11.614] & [5.833] & [5.579] \\
\hline \multirow{2}{*}{ Independent director } & 0.087 & 0.094 & $-0.116^{*}$ & $-0.103^{*}$ & -0.092 & -0.092 \\
\hline & {$[1.391]$} & [1.466] & {$[-1.963]$} & {$[-1.741]$} & {$[-0.371]$} & {$[-0.377]$} \\
\hline \multirow{2}{*}{ Audit and Risk Comm. } & $0.420 \% * *$ & & $0.412 * * *$ & & -0.057 & \\
\hline & {$[9.795]$} & & {$[9.300]$} & & {$[-0.227]$} & \\
\hline \multirow{2}{*}{ Remuneration Comm. } & $0.244 * * *$ & & $0.188 * \ldots *$ & & 0.011 & \\
\hline & {$[5.917]$} & & {$[4.672]$} & & {$[0.047]$} & \\
\hline \multirow{2}{*}{ Executive Comm. } & $0.431^{\text {*** }}$ & & $0.286^{* \kappa}$ & & -0.38 & \\
\hline & {$[3.496]$} & & [2.341] & & {$[-0.930]$} & \\
\hline \multirow{2}{*}{ N. of Comm. membership } & & $0.299 * * *$ & & $0.271 * * *$ & & 0.006 \\
\hline & & {$[8.828]$} & & {$[8.085]$} & & {$[0.028]$} \\
\hline Dummy year & YES & YES & YES & YES & YES & YES \\
\hline Dummy industry & YES & YES & YES & YES & YES & YES \\
\hline \multirow{2}{*}{ Constant } & $-2.044 * * *$ & $-1.952 * * *$ & $-1.034 * *$ & $-0.944 * *$ & -0.631 & -0.717 \\
\hline & {$[-4.230]$} & {$[-4.030]$} & {$[-2.587]$} & {$[-2.427]$} & {$[-0.297]$} & {$[-0.338]$} \\
\hline R-squared & 0.291 & 0.286 & 0.286 & 0.283 & 0.16 & 0.16 \\
\hline Observations & 11374 & 11374 & 11374 & 11374 & 11120 & 11120 \\
\hline
\end{tabular}

Note: OLS regressions with remuneration from the issuer and total remuneration (including subsidiaries) as dependent variables. Independent variables are described in the Appendix. ${ }^{* * *}=$ significant at the $1 \%$ level; $* *=$ significant at the $5 \%$ level; * $=$ significant at the $10 \%$ level.

Consistently with previous literature, we find that NED remuneration in Italy depends positively (and strongly) on company size. The signs for other firm characteristics are also in line with expectations (in particular that for previous year's ROA, an accounting measure of past performance); however, only the coefficients for Tobin's Q are statistically significant. Since Tobin's Q is a proxy for investment opportunities (and expected firm growth), this seems to imply that NED remuneration is positively related to firm complexity and benefits from monitoring. The implied effects are also economically significant: the coefficient for firm size in Model 1 implies that a 10\% increase in company size leads, on average, to a $3.1 \%$ growth in NED remuneration; in a similar vein, a $10 \%$ rise in Tobin's Q implies on average a $1.7 \%$ remuneration increase. Other firm characteristics, including ownership, are seemingly of little or no importance.

The coefficient of the independent director dummy in Models 3 and 4 indicates that independent directors (INEDs) are paid less than gray directors: the coefficient in Model 3 shows that independent directors are actually paid, on average, $12 \%$ less than gray NEDs. ${ }^{10}$ No significant difference emerges from Models 1 and 2, where the only

${ }^{10}$ Due to the logarithmic transformation of the dependent variable $y$, the impact of a change in the independent variable $x$ is estimated as $(\exp \beta-1)$, where $\beta$ is the coefficient associated with the independent variable $x$. 
remuneration paid by the issuer is considered implying that the pay difference is due to additional pay received from subsidiaries by gray directors. Independent directors usually receive only a fixed retainer and, possibly, remuneration for additional functions performed within the board, in line with explicit recommendations by the Italian Corporate Governance Code.

Directors appointed by minority shareholders are also paid less than their colleagues, even after controlling for the possibly different functions they perform within the board: the difference is a - both statistically and economically - significant $-14 \%$ at the company level (which rises to $-17 \%$ including remuneration from subsidiaries). Contrary to what has been observed in other countries, no gender pay gap is apparent among NEDs; the number of other positions held ("busyness") also seems to play no role in setting the remuneration policy.

As expected, the role played by NEDs within the board is an important factor in setting their remuneration. Apical NEDs (non-executive chairs and deputy chairs) are paid much more and are more often beneficiaries of variable remuneration. The coefficients in regressions 3 and 4, for instance, imply that NEDs holding apical positions receive, on average, a $170 \%$ increase in their remuneration. The coefficients in regressions 5 and 6 , on the other hand, imply that the probability for apical NEDs to get variable remuneration is more than three times as high as that for other NEDs.

Besides, we find that membership in a board committee (in Models 1 and 3) or in multiple committees (in Models 2 and 4) is associated with substantially higher remuneration: one additional committee membership involves, on average, a 34\% increase in NED remuneration. The level of additional pay depends on the nature of the committee: in line with expectations, additional remuneration is higher for members of the Executive and Audit $(+54 \%$ and $+52 \%$, respectively: see Model 1 in Table 2), and lower for those of the Remuneration committee (+27\%). Models 1 to 4 explain around 30\% of remuneration variance across NEDs.

Models 5 and 6 show the results of our analysis where the dependent variable is the likelihood of variable pay allowances. This issue is of particular interest as previous research highlighted that independent directors' behaviour may be affected by variable compensation. ${ }^{11}$ Our results show that variable remuneration (a rare event in Italy) is only weakly associated with firm characteristics: in particular, firm size seems to have no influence in this regard. Variable pay is more likely where ownership concentration and board size are lower: control shareholders may actually worry about the cost of variable remuneration (and the implied potential dilution for their own shares, in case of equity incentives), the more so the larger the number of potential beneficiaries; this result is also consistent with control shareholders and NEDs acting as substitutes in monitoring management (Adithipyangkul \& Leung, 2016). Variable pay is more likely for directors holding apical positions and less likely for "busy" directors, whose contribution to firm performance and value is -

${ }^{11}$ For example, Sengupta and Zhang (2015) show that - for independent board members - the average ratio of equity-based pay to total pay is positively related to a firm's disclosure quality. arguably - associated less with their monitoring functions than with their networking capacity.

It is well-known that independent directors' role is different from that played by gray directors; consequently, their remuneration may have a different level and structure, as confirmed by our descriptive statistics and also by results in Table 2 . Independent directors' remuneration deserves, therefore, a specific analysis. To gain further insights in this regard, we re-run our regressions on the subsample of INEDs.

We apply the same analytical framework used in Table 2, with only minimal changes. More specifically, besides dropping the "independent director" dummy, we add a "long tenure" dummy: this is aimed at capturing situations where a "seasoned" INED is qualified as independent by the firm, notwithstanding his/her crossing the conventional 9-year tenure threshold set out by the Italian CG Code. Table 3 reports our results when directors' pay is defined in terms of remuneration received by the issuer. ${ }^{12}$

In light of the specifications described above, Model 1 in Table 3 is directly comparable to Model 1 in Table 2. Goodness of fit is even better than in the previous analysis ( $\mathrm{R}^{2}$ increases from 29\% to 42\%). The results for individual factors are qualitatively similar, with some notable exceptions: the most remarkable is gender. Female independent directors are, actually, paid less than their male colleagues. The difference is both statistically (at the 1\% level) and economically significant: the coefficient in Model 1 implies that, after controlling for the functions they perform within the board, male independent directors are paid around 22\% more than their female colleagues. This is in sharp contrast with our results for NEDs in general; untabulated tests show that male gray directors are actually paid slightly less than their female counterparts; in this case, however, the difference is not statistically significant.

A second difference is that "busy" independent directors are paid more, implying that listed firms pay a premium for INEDs holding positions in other companies: the difference is statistically significant; however, the effect is rather small, since one additional position in other firms is associated, on average, with a $1.2 \%$ increase in remuneration. This relationship may be consistent both with a "networking value" and with a "reputation for good monitoring" story; since busy gray directors receive no additional compensation, the latter interpretation seems more plausible. Interestingly, the coefficient for the long tenure dummy is not significant, implying that "seasoned" independent directors are not paid more, and therefore that their risk of being captured by management/control shareholders (at least through additional pay) is low. We find no immediate evidence of cronyism in our data. The negative coefficient for minority directors (usually considered independent) is, also, no longer significant: minority directors are paid less than the average NED, but more or less in line with other independent directors.

Finally, independent directors' remuneration is negatively related to past firm performance. While

\footnotetext{
${ }^{12}$ Since independent directors are rarely beneficiaries of additional remuneration from subsidiaries (and - where this happens - the implied amounts are very low), our results do not change if remuneration is calculated in terms of total remuneration received (including subsidiaries).
} 
this is substantially consistent with expectations (INEDs are paid more where their contribution is more useful, i.e., where past firm performance has been disappointing), the coefficient is extremely small, implying that the relationship is hardly relevant from an economic viewpoint.

Table 3. Independent directors' (INED) remuneration

\begin{tabular}{|c|c|c|c|c|}
\hline & \multicolumn{4}{|c|}{ Remuneration from the issuer } \\
\hline & (1) & $(2)$ & (3) & (4) \\
\hline \multirow{2}{*}{ FirmSize } & $0.306 * * *$ & 0.317 *** & & \\
\hline & [12.612] & [14.646] & & \\
\hline \multirow{2}{*}{ ROA_1 } & $-0.000^{* * *}$ & 0 & & \\
\hline & {$[-2.236]$} & {$[0.487]$} & & \\
\hline \multirow{2}{*}{ Stock return_1 } & 0 & 0 & & \\
\hline & {$[0.030]$} & {$[-0.234]$} & & \\
\hline \multirow{2}{*}{ Firm's age } & -0.055 & 0.032 & & \\
\hline & {$[-0.877]$} & {$[0.705]$} & & \\
\hline \multirow{2}{*}{ TobinsQ } & 0.098 & $0.122 * *$ & & \\
\hline & [1.221] & {$[2.120]$} & & \\
\hline \multirow{2}{*}{ StandardDev. } & -0.003 & 0 & & \\
\hline & {$[-0.549]$} & [0.059] & & \\
\hline \multirow{2}{*}{ Board Size } & 0.121 & -0.115 & & \\
\hline & {$[0.964]$} & {$[-0.802]$} & & \\
\hline \multirow{2}{*}{ Ownership concentration } & 0 & 0 & & \\
\hline & {$[0.092]$} & {$[0.137]$} & & \\
\hline \multirow{2}{*}{ Minority director } & -0.042 & & $0.288 * * *$ & \\
\hline & {$[-0.777]$} & & [2.998] & \\
\hline \multirow{2}{*}{ Gender } & $0.195^{* * * \mathrm{k}}$ & & $0.281 * * *$ & \\
\hline & {$[3.760]$} & & [3.953] & \\
\hline \multirow{2}{*}{ Director busyness } & $0.012^{* * *}$ & & $0.019 * * *$ & \\
\hline & {$[2.478]$} & & [2.783] & \\
\hline \multirow{2}{*}{ Long tenure } & -0.052 & & 0.02 & \\
\hline & {$[-0.646]$} & & {$[0.158]$} & \\
\hline \multirow{2}{*}{ Apical position } & 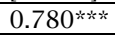 & & & $0.733^{\text {*** }}$ \\
\hline & {$[5.842]$} & & & {$[3.722]$} \\
\hline \multirow{2}{*}{ Audit and Risk Comm. } & $0.384 * * *$ & & & $0.145^{* * * *}$ \\
\hline & {$[9.380]$} & & & [3.108] \\
\hline \multirow{2}{*}{ Remuneration Comm. } & 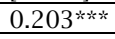 & & & 0.057 \\
\hline & [4.966] & & & [1.175] \\
\hline \multirow{2}{*}{ Executive Comm. } & $0.479 * * *$ & & & $0.713^{* * *}$ \\
\hline & {$[5.296]$} & & & [4.425] \\
\hline Dummy year & YES & YES & YES & YES \\
\hline Dummy industry & YES & YES & YES & YES \\
\hline \multirow{2}{*}{ Constant } & $-1.750 * *$ & $-1.533^{*} * * *$ & $2.839 * * *$ & $1.317 \% * *$ \\
\hline & {$[-2.443]$} & {$[-3.188]$} & [6.557] & {$[4.800]$} \\
\hline R-squared & 0.422 & 0.328 & 0.123 & 0.11 \\
\hline Observations & 4759 & 7497 & 5591 & 9210 \\
\hline
\end{tabular}

Note: OL S regressions with remuneration from the issuer and total remuneration (including subsidiaries) as dependent variables. Independent variables are described in the Appendix. $* * *=$ significant at the $1 \%$ level; $* *=$ significant at the $5 \%$ level; $*=$ significant at the $10 \%$ level

Models 2, 3 and 4 in Table 3 investigate the relative importance of various factors potentially affecting remuneration. Model 2 shows that firm characteristics (and, in particular, firm size) are, by far, the most important determinants of INED remuneration: $\mathrm{R}^{2}$ in Model 2 is 33\% (vs. $42 \%$ in Model 1), implying that their explanatory power accounts for around $3 / 4$ of INED remuneration variance. Untabulated tests show that firm size alone (plus industry and year fixed effects) accounts for $30 \%$ of independent directors' remuneration industry and year fixed effects account for 9\% of total variance. Models 3 and 4 show that, though statistically significant, both individual director characteristics and functions have little additional explanatory power. ${ }^{13}$
As already noted, the Italian regulatory and institutional environment changed remarkably over time. Share blocking before AGMs was banned after 2010 , thereby greatly increasing the effectiveness of the record date system. Most importantly, SOP was mandated in all listed companies starting with 2012 AGMs; in the same year, gender quotas became effective for board elections. To trace the possible effects of changes in the institutional environment, we repeated our analysis for INEDs on different subperiods (2007-2011 vs. 2012-2015). Table 4 reports our results. 
Table 4. Independent directors' (INED) remuneration: Analysis by subperiods

\begin{tabular}{|c|c|c|c|c|c|c|}
\hline & \multicolumn{2}{|c|}{$(2007-2011)$} & \multicolumn{2}{|c|}{$(2012-2015)$} & \multicolumn{2}{|c|}{$(2013-2015)$} \\
\hline & (1) & (2) & (3) & (4) & (5) & (6) \\
\hline \multirow{2}{*}{ FirmSize } & $0.331 * * *$ & $0.328 * * *$ & $0.289 * * *$ & $0.286^{* * * *}$ & $0.333 * * *$ & $0.327 * * *$ \\
\hline & [12.431] & [12.510] & {$[8.757]$} & {$[8.479]$} & [8.942] & [8.555] \\
\hline \multirow{2}{*}{ ROA_1 } & -0.003 & -0.001 & 0 & 0 & 0 & 0 \\
\hline & {$[-0.412]$} & {$[-0.200]$} & [-1.513] & {$[-1.137]$} & {$[-0.454]$} & {$[0.017]$} \\
\hline \multirow{2}{*}{ Stock return_1 } & 0 & 0 & 0 & 0 & -0.001 & -0.001 \\
\hline & [0.193] & {$[0.246]$} & {$[0.474]$} & {$[0.422]$} & {$[-0.728]$} & {$[-0.910]$} \\
\hline \multirow{2}{*}{ Firm's age } & -0.09 & -0.074 & -0.063 & -0.05 & -0.055 & -0.045 \\
\hline & {$[-1.128]$} & {$[-0.941]$} & {$[-0.908]$} & {$[-0.707]$} & {$[-0.626]$} & {$[-0.498]$} \\
\hline \multirow{2}{*}{ TobinsQ } & -0.152 & -0.168 & $0.172 * * *$ & $0.169 * * *$ & $0.172 * * *$ & $0.171 * * *$ \\
\hline & {$[-0.514]$} & {$[-0.570]$} & [3.142] & [3.093] & {$[3.594]$} & {$[3.544]$} \\
\hline \multirow{2}{*}{ StandardDev. } & -0.005 & -0.006 & -0.002 & -0.002 & 0.004 & 0.006 \\
\hline & {$[-0.764]$} & {$[-0.816]$} & {$[-0.268]$} & {$[-0.213]$} & [0.520] & [0.660] \\
\hline \multirow{2}{*}{ Board size } & 0.023 & -0.021 & 0.15 & 0.148 & -0.048 & -0.03 \\
\hline & {$[0.133]$} & {$[-0.126]$} & {$[0.888]$} & {$[0.858]$} & {$[-0.255]$} & {$[-0.156]$} \\
\hline \multirow{2}{*}{ Ownership concentration } & -0.001 & -0.001 & 0.002 & 0.003 & 0.005 & $0.006^{*}$ \\
\hline & {$[-0.350]$} & {$[-0.313]$} & {$[0.660]$} & {$[0.886]$} & {$[1.650]$} & [1.957] \\
\hline \multirow{2}{*}{ Minority director } & -0.036 & -0.025 & -0.062 & -0.047 & -0.052 & -0.027 \\
\hline & {$[-0.549]$} & {$[-0.372]$} & {$[-1.050]$} & {$[-0.772]$} & {$[-0.601]$} & {$[-0.299]$} \\
\hline \multirow{2}{*}{ Gender } & $0.362 * *$ & $0.350 * *$ & $0.155^{* * * *}$ & 0.138 *** & 0.068 & 0.05 \\
\hline & {$[2.576]$} & [2.461] & {$[2.962]$} & {$[2.615]$} & [1.245] & [0.898] \\
\hline \multirow{2}{*}{ Director busyness } & $0.013 * *$ & $0.013 * *$ & 0.007 & 0.005 & $0.017^{*}$ & $0.015^{*}$ \\
\hline & [2.342] & [2.321] & {$[0.985]$} & {$[0.750]$} & [1.946] & [1.787] \\
\hline \multirow{2}{*}{ Long tenure } & 0.006 & 0.019 & -0.073 & -0.041 & -0.065 & -0.037 \\
\hline & {$[0.067]$} & {$[0.212]$} & {$[-0.848]$} & {$[-0.466]$} & {$[-0.697]$} & {$[-0.383]$} \\
\hline \multirow{2}{*}{ Apical position } & $0.859 * \cdots *$ & $0.850 * * *$ & 0.664 *** & 0.707 *** & $0.494 * * *$ & $0.531^{* * * *}$ \\
\hline & {$[4.952]$} & {$[5.006]$} & [6.993] & {$[7.227]$} & [5.213] & {$[5.008]$} \\
\hline & 0.384 *** & & 0.390 *** & & $0.389 * * *$ & \\
\hline Audit and Risk Comm. & {$[6.531]$} & & {$[9.014]$} & & [6.815] & \\
\hline Remuneration Comm & $0.223^{* * * * *}$ & & 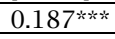 & & 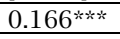 & \\
\hline Remuneration comm. & {$[4.068]$} & & {$[4.141]$} & & [3.052] & \\
\hline & $0.421 * * *$ & & $0.491^{* * * *}$ & & $0.444 * * *$ & \\
\hline Executive Comm. & [3.423] & & {$[5.326]$} & & {$[4.007]$} & \\
\hline N of Comm momberchin & & $0.264 * * *$ & & $0.270 * * *$ & & $0.257 * \cdots *$ \\
\hline N. of Comm. membersnip & & [6.098] & & [6.840] & & {$[5.901]$} \\
\hline & & & & & $0.324 *$ & $0.330 *$ \\
\hline 11A & & & & & {$[1.714]$} & {$[1.767]$} \\
\hline & & & & & -0.063 & -0.062 \\
\hline Politically exposed & & & & & {$[-1.064]$} & {$[-1.072]$} \\
\hline Graduate & & & & & -0.027 & -0.046 \\
\hline Graduate & & & & & {$[-0.426]$} & {$[-0.686]$} \\
\hline Foreion deoree & & & & & 0.062 & 0.045 \\
\hline Forelgn degree & & & & & {$[0.606]$} & {$[0.461]$} \\
\hline & & & & & 0.029 & 0.048 \\
\hline Manager & & & & & {$[0.284]$} & [0.482] \\
\hline Concultant & & & & & 0.01 & 0.043 \\
\hline consultant & & & & & {$[0.114]$} & {$[0.496]$} \\
\hline & & & & & 0.152 & 0.158 \\
\hline Academic & & & & & [1.475] & [1.506] \\
\hline Retired & & & & & 0.034 & -0.047 \\
\hline Retıred & & & & & {$[0.455]$} & {$[-0.635]$} \\
\hline Dummy year & YES & YES & YES & YES & YES & YES \\
\hline Dummy industry & YES & YES & YES & YES & YES & YES \\
\hline & -1.607 & -1.45 & $-1.412 * *$ & $-1.443^{* *}$ & $-2.380 * * *$ & -2.438 *** \\
\hline Constant & {$[-1.406]$} & {$[-1.300]$} & {$[-2.082]$} & {$[-2.108]$} & {$[-2.856]$} & {$[-2.858]$} \\
\hline R-squared & 0.425 & 0.42 & 0.449 & 0.439 & 0.473 & 0.463 \\
\hline Observations & 2585 & 2585 & 2174 & 2174 & 1198 & 1198 \\
\hline
\end{tabular}

Note: OLS regressions with Remuneration from the issuer as the dependent variable. Independent variables are described in the Appendix. ${ }^{* * * *}=$ significant at the $1 \%$ level; ${ }^{* *}=$ significant at the $5 \%$ level; ${ }^{*}=$ significant at the $10 \%$ level

The general framework is confirmed in both subperiods. Firm size remains, by far, the most important factor in setting the remuneration of independent directors; the functions performed by INEDs (apical positions, committee memberships) are also important. The impact of other factors, however, changed remarkably. This is true, in particular, for Tobin's Q, whose coefficient becomes positive and strongly statistically significant only after the introduction of SOP: since Tobin's Q is a proxy for firm complexity and investment opportunities, we interpret this evidence as consistent with INED remuneration becoming increasingly related to the potential benefits associated with their monitoring. This effect is unique to independent directors (Tobin's Q does not impact significantly on the remuneration of gray directors).

Moving to individual directors' characteristics, Table 4 shows that the gender pay gap has gradually disappeared: the coefficient for the gender dummy drops by more than half after SOP (from 0.36 in Model 1 to 0.15 in Model 3): male independent directors were paid 43\% (16\%) more than their female colleagues before (after) SOP. The huge increase in board gender diversity following the introduction of quotas has been accompanied by a remarkable decrease in the gender pay gap. A 
similar drop is observable for the coefficient for "busyness", which is no longer statistically significant: we interpret this evidence as consistent with listed firms giving more weight - after SOP - to costs/inefficiencies from the limited time commitment, than to benefits from higher reputation/networking capacity.

Models 5 and 6 in Table 4 report the results of the further analysis conducted on more recent years (2013-2015), where additional data on individual directors' characteristics are available. We consider INED nationality, political exposure, education ("graduate" and "foreign degree" dummies ${ }^{14}$ ) and main profession ("manager" in other companies, "consultant" - mainly accountants and lawyers "academic" and "retired"). The general picture for post-SOP years is substantially confirmed: the richer data set for director qualifications adds little or no explanatory power. Only the nationality dummy is marginally significant; contrary to our expectations, however, foreign directors are paid less than their Italian colleagues. Contrary to previous evidence for the UK and US (Goh \& Gupta, 2015, Fedaseyeu et al., 2018) education and the main profession have little or no impact on INED remuneration.

As evident from Models 5 and 6 we find no trace of a gender pay gap in the 2013-2015 period: the coefficient for gender drops further (to 0.068 in Model 5) and is no longer statistically significant. The disappearance of the gender pay gap is not due to the introduction of additional variables in the regressions. Instead, this phenomenon is apparently associated with the mere passing of time. Further analyses conducted on subsamples reveal that the coefficient for gender, still positive and significant in 2012 and 2013, becomes negative and insignificant in years 2014 and 2015. After controlling for firm characteristics and functions performed by independent directors, the gender pay gap seems just a memory of the past.

\section{CONCLUSION}

We study the determinants of NED (and in particular independent directors') remuneration in Italy over a rather long time period (2007-2015), which allows us to trace possible evolutions in response to a changing institutional environment. Our main results may be summarized as follows:

- NED remuneration is strongly affected by firm characteristics, in particular by firm size, which accounts for $3 / 4$ of explained variance across independent directors. Independent directors are paid less than gray directors; the gap between the two categories is, however, gradually closing, due to lower additional compensation being paid to gray directors in subsidiaries. Contrary to what happened elsewhere, independent directors' pay increased only by a small amount (around 10\%).

- NED remuneration is also associated with the functions performed by individual directors within the board (apical positions, committee memberships). On the contrary, individual directors' characteristics have little or no impact on directors pay. We find evidence of a gender pay gap among independent (but not among gray) directors; however, this gap has gradually disappeared in

${ }^{14} \mathrm{We}$ tried alternative specifications, including dummies for the degree type (economics, law, engineering, other, alternatively) with similar results. conjunction with the growing number and role of female directors, following the adoption of mandatory board gender quotas.

- The relationship between INED pay and some variables of interest changed over time. Independent directors' remuneration is increasingly, positively associated with Tobin's Q (a proxy for the benefits from monitoring). On the opposite, director "busyness" is no longer a significant factor in this regard. The changes we observe are apparently consistent with the market for directors' pay in Italy becoming more mature after the introduction of Sayon-Pay and other regulation favouring investor activism. This is also consistent with a positive role played by both institutional investors and their representatives sitting on the board of listed companies after the introduction of said legislation.

Although the evolution of the relationship between NED remuneration and both firm and individual characteristics looks positive, our analysis raises some questions about the efficiency of the market for individual directors' pay in Italy, which could be properly addressed by future research.

First, remuneration appears to be overwhelmingly determined by firm size and, to some extent, by the role NEDs play within the board, in terms of apical positions and/or committee memberships. While we produce no general theory of an "optimal" remuneration policy, our analysis raises some doubts about the efficiency of such scheme, in light of the explicit recommendations of the Italian CG Code: do remuneration policies take into account all relevant factors in order to "attract, retain and motivate people with the professional skills necessary to successfully manage the issuer"? Or are they set according to a benchmarking process based almost exclusively on comparables defined in terms of sheer firm size (and industry), leaving little room to consider the directors' qualities needed in individual firms?

Actually, what we see is apparently consistent with a "herding" behavior of firms following a sizeand-directors' role model in setting NED remuneration, which may - after all - be suboptimal. Increasing engagement by institutional investors blindly following stereotyped recommendations coming from proxy advisors may reinforce this trend. While our evidence shows that the impact of SOP and the related investor activism has, so far, been positive, we wonder if (and how) the engagement model followed so far may be further improved.

Our evidence shows very different evolutions of NED remuneration over time: gray directors' pay decreased, due to lower remuneration from subsidiaries, which may be positive in terms of their incentive alignment; however, independent directors' pay - which was in line with that of their UK counterparts in 2007 - increased by a negligible amount (€6,000 on average) in 9 years, notwithstanding a major increase in directors' functions, time commitment, and responsibilities. This evolution, in sharp contrast with what happened elsewhere, is puzzling, and raises a number of questions, e.g.: Are independent directors paid "enough" for their job? Do they perform a substantial role in board dynamics or are they merely "financial gigolos", hired (and paid moderately) to give a superficial coat of paint to company

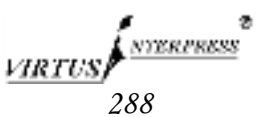


governance? Why don't institutional investors actively engage to link directors' pay more directly to their increasing responsibilities?

A different question arises regarding the structure of NED remuneration. The Italian CG Code (in line with its UK predecessor) expressed a clear preference for NEDs receiving only a fixed retainer (plus fees for committee memberships and possibly attendance fees): little room is left for variable pay, which is - on the opposite - the rule in the US and in Germany. Consequently, non-executive (and, even more so, independent) directors received variable components of remuneration is less than $2 \%$ of the cases. Furthermore, the recourse to variable pay has dropped by more than half in our sample period. Inevitably, then, the question arises: has the Italian CG Code gone too far in cautioning against variable remuneration for NEDs?

The main limitations of our analysis show some directions for future research. First, a richer set of variables might allow shedding further light on the role of gray and independent directors: ownership structure is a likely candidate for a more in-depth investigation. We analyzed ownership concentration, but other dimensions may also be relevant: for example, nature (family vs. non-family) of the controlling shareholder may have an influence on the role (and the impact) of independent directors on the board and, therefore, on their remuneration.
Second, related literature showed that SOP has become a favourite battleground for the growing activism by institutional investors; this happened often on the basis of negative recommendations by international proxy advisors, whose influence has increased dramatically over the last few years; Italy has been no exception in this regard. An interesting point is that criticisms have mainly focused on purportedly "excessive" CEO pay packages, while little attention has apparently been devoted to possibly "insufficient" INED remuneration. Further research, based on a careful analysis of proxy recommendations and shareholder voting (publicly available in Italy) on this topic may be in order. NED remuneration dynamics could also be investigated, focusing on the possible link between investor activism and changes in NED remuneration: does shareholder dissent on a firm remuneration policy lead to subsequent changes in directors' pay package, not only for the CEO but also for NEDs?

Lastly, it could be interesting to investigate whether NED remuneration has an impact on how NEDs actually monitor company management: a way to do this might be to analyze the behavior of firms adopting different NED remuneration policies when confronted with individual, relevant corporate decisions.

Additional research is needed to address these questions systematically.

\section{REFERENCES}

1. Adams, R. B. (2017). Boards, and the directors who sit on them (ECGI Finance Working Paper No. 515/2017). https://doi.org/10.2139/ssrn.3002219

2. Adams, R. B., \& Ferreira, D. (2008). Do directors perform for pay? Journal of Accounting and Economics, 46(1), 154-171. https://doi.org/10.1016/j.jacceco.2008.06.002

3. Adithipyangkul, P, \& Leung, T. Y. (2016). Large shareholders and independent director equity compensation. Australian Accounting Review, 26(2), 208-221. https://doi.org/10.1111/auar.12097

4. Andreas, J. M., Rapp, M. S., \& Wolff, M. (2012). Determinants of director compensation in two-tier systems: Evidence from German panel data. Review of Managerial Science, 6(1), 33-79.

5. Armour, J., Awrey, D., Enriques, L., Gordon, J. N., Mayer, C., \& Payne, J. (2016). Bank Governance (ECGI Law Working Paper No. 316/2016). Retrieved from https://ecgi.global/sites/default/files/ working_papers/documents/SSRN-id2793112.pdf

6. Assonime-Emittenti Titoli. (2018). Corporate governance in Italy: Compliance, remuneration and comply-orexplain (Report). Retrieved from Assonime-Emittenti Titoli website: www.assonime.it

7. Becht, M., Bolton, P., \& Röell, A. (2012). Why bank governance is different. Oxford Review of Economic Policy, 27(3), 437-463. https://doi.org/10.1093/oxrep/grr024

8. Belcredi, M., \& Enriques, L. (2015). Institutional investor activism in a context of concentrated ownership and high private benefits of control: The case of Italy. In R. Thomas, \& J. Hill (Eds.), Research handbook on shareholder power (pp. 383-403). Cheltenham, UK: Edward Elgar Publishing. https://doi.org/ $10.4337 / 9781782546856.00034$

9. Belcredi, M., Bozzi, S., \& Di Noia, C. (2013). Board elections and shareholder activism: The Italian experiment. In M. Belcredi, \& G. Ferrarini (Eds.), Boards and shareholders in European listed companies: Facts, context and postcrisis reforms (pp. 365-421). Cambridge University Press. https://doi.org/10.1017/СBO9781139629126.008

10. Belcredi, M., Bozzi, S., Ciavarella, A., \& Novembre, V. (2017). Institutional investors' activism under concentrated ownership and the role of proxy advisors. Evidence from the Italian say-on-pay. Corporate Ownership \& Control, 14(4), 41-57. https://doi.org/10.22495/cocv14i4art4

11. Brick, I. E., Palmon, O., \& Wald, J. K. (2006). CEO Compensation, director compensation, and firm performance: Evidence of cronyism? Journal of Corporate Finance, 12(3), 403-423. https://doi.org/ 10.1016/j.jcorpfin.2005.08.005

12. Bryan, S., Hwang, L. S., Klein, A., \& Lilien, S. (2000). Compensation of outside directors: An empirical analysis of economic determinants. https://doi.org/10.2139/ssrn.244540

13. Consob. (2017). Report on Corporate Governance of Italian Listed Companies. Retrieved from http://www.consob.it/web/consob-and-its-activities/rcg2017

14. Cools, S. (2005). The real difference in corporate law between the United States and continental Europe: Distribution of powers (Discussion Paper No. 490, Harvard Law and Economics). https://doi.org/10.2139/ssrn.623286

15. Dah, M. A., \& Frye, M. B. (2017). Is board compensation excessive? Journal of Corporate Finance, 45, 566-585. https://doi.org/10.1016/j.jcorpfin.2017.06.001

16. Dyck, A., \& Zingales, L. (2004). Private benefits of control: An international comparison. Journal of Finance, 59(2), 537-600. https://doi.org/10.1111/j.1540-6261.2004.00642.x 
17. Engel, E., Hayes, R. M., \& Wang, X. (2010). Audit committee compensation and the demand for monitoring of the financial reporting process. Journal of Accounting and Economics, 49(1-2), 136-154. https://doi.org/ 10.1016/j.jacceco.2009.08.001

18. Farrell, K. A., Friesen, G. C., \& Hersch, P. L. (2008). How do Firms adjust Director Compensation? Journal of Corporate Finance, 14(2), 153-162. https://doi.org/10.1016/j.jcorpfin.2008.02.004

19. Fedaseyeu, V., Linck, J. S., \& Wagner, H. F. (2018). Do qualifications matter? New evidence on board functions and director compensation. Journal of Corporate Finance, 48, 816-839. https://doi.org/ 10.1016/j.jcorpfin.2017.12.009

20. Ferris, S. P., Jagannathan, M., \& Pritchard, A. C. (2003). Too busy to mind the business? Monitoring by directors with multiple board appointments. Journal of Finance, 58(3), 1087-1111. https://doi.org/10.1111/15406261.00559

21. Fich, E. M., \& Shivdasani, A. (2006). Are busy boards effective monitors? Journal of Finance, 61(2), 689-724. https://doi.org/10.1111/j.1540-6261.2006.00852.x

22. Goh, L., \& Gupta, H. (2015). Remuneration of non-executive directors: Evidence from the UK. The British Accounting Review, 48(3), 379-399. https://doi.org/10.1016/j.bar.2015.05.001

23. Hermalin, B. E., \& Weisbach, M. S. (1988). The determinants of board composition. RAND Journal of Economics, 19(4), 589-606. https://doi.org/10.2307/2555459

24. Hope, O. K., Lu, H., \& Saiy, S. (2019). Director compensation and related party transactions. Review of Accounting Studies, 24(4), 1392-1426. https://doi.org/10.1007/s11142-019-09497-w

25. Korn-Ferry. (2016). Non-executive directors in Europe 2015: Pay practices, structures and diversity of leading European companies. Retrieved from https://dcgi.org/wp-content/uploads/2016/12/NEDs_report_2016_WEB.pdf

26. Linck, J. S., Netter, J. M., \& Yang, T. (2009). The effects and unintended consequences of the Sarbanes-Oxley Act on the supply and demand for directors. The Review of Financial Studies, 22(8), 3287-3328. https://doi.org/10.1093/rfs/hhn084

27. Macey, J. R. (1998). Italian corporate governance: One American's perspective. Columbia Business Law Review, 1 , 121-144. Retrieved form https://pdfs.semanticscholar.org/ba24/2db7182b493eca07e8a4e56e1b0b42714d21.pdf

28. Mallin, C., Melis, A., \& Gaia, S. (2015). The remuneration of independent directors in the UK and Italy: An empirical analysis based on agency theory. International Business Review, 24(2), 175-186. https://doi.org/10.1016/j.ibusrev.2014.07.006

29. Masulis, R. W., \& Mobbs, S. (2014). Independent director incentives: Where do talented directors spend their limited time and energy? Journal of Financial Economics, 111(2), 406-429. https://doi.org/ 10.1016/j.jfineco.2013.10.011

30. Masulis, R. W., \& Zhang, E. J. (2019). How valuable are independent directors? Evidence from external distractions. Journal of Financial Economics, 132(3), 226-256. https://doi.org/10.1016/j.jfineco.2018.02.014

31. Nguyen, N. Q. (2014). On the compensation and activity of corporate boards. Journal of Corporate Finance, 29, 1-19. https://doi.org/10.1016/j.jcorpfin.2014.06.004

32. Ryan, H. E., \& Wiggins, R. A. (2004). Who is in whose pocket? Director compensation, board independence, and barriers to effective monitoring. Journal of Financial Economics, 73(3), 497-524. https://doi.org/ 10.1016/j.jfineco.2003.11.002

33. Sengupta, P., \& Zhang, S. (2015). Equity-based compensation of outside directors and corporate disclosure quality. Contemporary Accounting Research, 32(3), 1073-1098. https://doi.org/10.1111/1911-3846.12115

34. Yermack, D. (2004). Remuneration, retention, and reputation incentives for outside directors. The Journal of Finance, 59(5), 2281-2308. https://doi.org/10.1111/j.1540-6261.2004.00699.x 


\section{APPENDIX}

\section{Definition of the variables}

\begin{tabular}{|c|c|c|c|}
\hline Variable Group & Variable & Description & Type of variable \\
\hline \multirow[t]{2}{*}{ Compensation } & Remuneration from the issuer & Director total compensation from the issuer & $\begin{array}{l}\text { Log of director's compensation from the entity } \\
\text { (Salary+Bonus+Other annual benefits+ Equity- } \\
\text { based pay + Severance pay) }\end{array}$ \\
\hline & $\begin{array}{l}\text { Total remuneration (including } \\
\text { subsidiaries) }\end{array}$ & Director total compensation including subsidiaries & $\begin{array}{l}\text { Log of the sum of base compensation and } \\
\text { compensation from controlled companies }\end{array}$ \\
\hline \multirow{6}{*}{$\begin{array}{l}\text { Firm } \\
\text { characteristics }\end{array}$} & FirmSize & Firm's size & Log of Total assets \\
\hline & Tobin'sQ & Growth opportunities and complexity & $\begin{array}{l}\text { Log of ((Total assets - Book value of } \\
\text { shareholders' equity + Market value of } \\
\text { shareholders' equity)/Total assets)) }\end{array}$ \\
\hline & StandardDev & Firm's risk & Standard deviation of stock returns \\
\hline & Stock return & Stock performance & Annual stock market returns \\
\hline & ROA & Return on asset & EBIT/Total asset \\
\hline & Firm's age & Number of years since the IPO & Log(firm's age) \\
\hline \multirow{2}{*}{$\begin{array}{l}\text { Governance } \\
\text { characteristics }\end{array}$} & BoardSize & Board size & $\begin{array}{l}\text { Log of board members count (nelle società con } \\
\text { dualistico è C Sorv+C Gest) }\end{array}$ \\
\hline & Ownership concentration & Voting rights of the first owner & Voting rights of the first owner \\
\hline \multirow{15}{*}{$\begin{array}{l}\text { Director } \\
\text { characteristics }\end{array}$} & Director busyness & Number of other boards served on by the firm's director & $\begin{array}{l}\text { Number of other boards served on by the firm's } \\
\text { director }\end{array}$ \\
\hline & N. of Committees membership & $\begin{array}{l}\text { Number of Committees served on by the firm's director participation to Board } \\
\text { Committees }\end{array}$ & $(\mathrm{CN}+\mathrm{CCI}+\mathrm{CR})$ \\
\hline & Gender & A dummy variable equal to 1 if the director is a female and 0 otherwise & Dummy $(1 ; 0)$ \\
\hline & Long tenure & $\begin{array}{l}\text { A dummy variable equal to } 1 \text { if the director has been on the board for more than nine } \\
\text { years and } 0 \text { otherwise }\end{array}$ & Dummy $(1 ; 0)$ \\
\hline & Independent director & A dummy variable equal to 1 if the director is independent and 0 otherwise & Dummy $(1 ; 0)$ \\
\hline & Minority director & $\begin{array}{l}\text { A dummy variable equal to } 1 \text { if the director is elected by minority shareholders and } 0 \\
\text { otherwise }\end{array}$ & Dummy $(1 ; 0)$ \\
\hline & Chairman & $\begin{array}{l}\text { A dummy variable equal to } 1 \text { if the director is the chairman of the board and } 0 \\
\text { otherwise }\end{array}$ & Dummy $(1 ; 0)$ \\
\hline & Apical position & $\begin{array}{l}\text { A dummy variable equal to } 1 \text { if the director is the director has an apical position } \\
\text { (Chairman, Vice-chairman, etc.) and } 0 \text { otherwise. }\end{array}$ & Dummy $(1 ; 0)$ \\
\hline & Committee director's membership & $\begin{array}{l}\text { A set of dummy variables for the membership in Board Committees (Audit and Risk, } \\
\text { Nomination, Remuneration Committees and Executive Board) }\end{array}$ & Dummy $(1 ; 0)$ \\
\hline & Italian director & A dummy variable equal to 1 if the director has Italian nationality and 0 otherwise & Dummy $(1 ; 0)$ \\
\hline & Graduate & A dummy variable equal to 1 if the director has a graduate degree and 0 otherwise & Dummy $(1 ; 0)$ \\
\hline & Type of degree & $\begin{array}{l}\text { A set of dummy variables for the type of graduate degree (Economics, Law, } \\
\text { Engineering, etc.) }\end{array}$ & Set of dummies $(1 ; 0)$ \\
\hline & Foreign degree & A dummy variable equal to 1 if the director has a foreign degree and 0 otherwise & Dummy $(1 ; 0)$ \\
\hline & Director's main profession & $\begin{array}{l}\text { A set of dummy variables for director's main profession (manager, consultant, } \\
\text { academic, etc.) }\end{array}$ & Dummy $(1 ; 0)$ \\
\hline & The director is politically exposed & A dummy variable equal to 1 if the director is politically exposed and 0 otherwise & Dummy $(1 ; 0)$ \\
\hline \multirow{2}{*}{$\begin{array}{l}\text { Time and } \\
\text { industry control } \\
\text { variables }\end{array}$} & Year t & Year dummies & Set of dummies $(1 ; 0)$ \\
\hline & Industry & Industry dummies & $\begin{array}{l}\text { Set of dummies (1; 0), based on Campbell (1996) } \\
\text { classification }\end{array}$ \\
\hline
\end{tabular}

